Nat. Hazards Earth Syst. Sci. Discuss., https://doi.org/10.5194/nhess-2017-253

Manuscript under review for journal Nat. Hazards Earth Syst. Sci.

Discussion started: 13 July 2017

(c) Author(s) 2017. CC BY 4.0 License.

\title{
Prediction of rainfall induced landslide movements by artificial neural networks
}

\author{
Janko Logar ${ }^{1}$, Goran Turk ${ }^{1}$, Peter Marsden ${ }^{2}$, Tomaž Ambrožič ${ }^{1}$ \\ ${ }^{1}$ Faculty of Civil and Geodetic Engineering, University of Ljubljana, Jamova cesta 2, 1000 Ljubljana, Slovenia \\ $5 \quad{ }^{2}$ Coastal Management Isle of Wight Council, Salisbury Gardens, Dudley Road, Ventnor, Isle of Wight, PO38 1EJ, UK
}

Correspondence to: Janko Logar (janko.logar@fgg.uni-lj.si)

\begin{abstract}
Many slow to moderate landslides are monitored in order to react on time and prevent loss of lives and reduce material damage. In most of such cases there are very limited data on the geometry, hydrogeological and material properties of the landslide. The aim of the paper is to test the ability of artificial neural networks (ANN) to make reliable short term

10 predictions of rainfall induced landslide movements based on normally available data: rainfall and measured displacements. The back propagation artificial neural network was trained and tested for two sliding phenomena, which are very different in nature. One is moderately moving earthflow and the other very slow landslide, with maximum rate of movements 600 $\mathrm{mm} /$ day and $0.094 \mathrm{~mm} /$ day, respectively. The results show that in both cases a trained ANN can predict landslide movements with sufficient reliability and can therefore be used together with weather forecast to assist authorities when

15 faced with difficult decisions, such as evacuation. The accuracy of the ANN prediction of movements depends on the type and architecture of ANN as well as on the organisation of the input data used for training, as it is shown by case histories.
\end{abstract}

\section{Introduction}

The assessment of landslide movements is a wide topic, addressed by a number of authors. This is not surprising since landslides worldwide cause significant impact to build and natural environment and their mitigation has significant financial consequences (Lacasse, 2013). The reliable prediction of landslide occurrence, its velocity and influence area still remains a challenge (Yao et al. 2015). Thiebes et al. (2014) report on successful use of physically based slope stability model combined with hydrological model as early warning system. Such approach is only possible in cases of existing landslides for which the ground composition and properties are well investigated. For many landslides the available geological and geotechnical data are very limited. However, there are numerous landslides with displacement monitoring systems. For such 25 landslides it shouldn't be too difficult to study the evolution of its displacements vs. time taking into account relevant influencing parameters with the aim to make the accurate short term prediction of their further movements. Reliable short term predictions of landslide movements are of extreme importance for civil protection and stakeholders that have the responsibility to decide on such extreme measures as evacuations or closing of roads/railways. 
Nat. Hazards Earth Syst. Sci. Discuss., https://doi.org/10.5194/nhess-2017-253

Manuscript under review for journal Nat. Hazards Earth Syst. Sci.

Discussion started: 13 July 2017

(c) Author(s) 2017. CC BY 4.0 License.

Monitoring of surface movements of landslides, creeping slopes of viscous earthflows is normally put in place in order to document the behaviour, delimit the stable and non-stable area, enhance understanding of landslide behaviour (e.g. establish correlations with rainfall as the most often cause of movements), assess probable future behaviour, plan effective engineering mitigation measures, issue warning when necessary.

5 The latter is of special importance when landslide or earthflow gradually progresses down the slope and poses a threat for settlements along the streamline and/or below the front of the earthflow. In such cases it is essential to protect the lives and property. Since the rate of movements of an earthflow or landslide depends on many factors (e.g. rainfall, topography, geology, material properties, groundwater conditions) it is nearly impossible to predict these movements in advance with required accuracy. When movements are monitored together with rainfall data and other relevant information in the course

10 of months and years a database of recorded movements together with main influencing parameters may be built, which could present a valuable source of knowledge for the particular earthflow. The dependence between movements (rate of movements), rainfall history, temperatures, slope inclination, and other data is usually very complex and can't be written in a closed mathematical form. One possible method to approximate the observed earthflow behaviour is to use the artificial neural networks (ANN).

15 A number of papers report on successful use of machine learning procedures in order to map landslide prone areas or assess landslide susceptibility (e.g. Conforti et al. 2014; Dou et al. 2015; Ermini et al. 2005; Goetz et al. 2015; Nourani et al. 2014; Pradha et al. 2011; Pradhan and Lee, 2009; Wang et al. 2016), estimate slope stability (e.g. Alimohammadlou, 2014; Gelisli et al. 2015; Li et al. 2014; Lu and Rosenbaum, 2003) or predict landslide movements (Chen and Zeng, 2013; Chen HQ et al. 2012; Chen J et al. 2015; Chen Y et al. 2012; Gao, 2010; Li et al. 2012; Lian et al. 2012a, 2012b, 2013, 2015; Mayoraz,

20 1996; Mayoraz and Vulliet, 2002; Ran et al. 2010; Yao et al. 2015, Zeng et al. 2008).

Mayoraz et al. (1996) and Mayoraz and Vulliet (2002) predicted slope movements by neural networks based on rainfall, measured pore pressures and rate of displacements. The velocity of the sliding soil mass was predicted based on meteorological and physical data and using different neural network configurations. Lu and Rosenbaum (2003) used the combination of ANN and Grey Systems methods to predict the likely state of stability for a slope and landslide movements.

25 They state that the power of the ANN and Grey Systems approaches lies in employing the behaviour of the system rather than knowledge of explicit relations. Zeng et al. (2008) adopted Radial Basis Function (RBF) neural network for the assessment of landslide movement: The use of multivariable time series model was more successful than single variable time series model. In addition to measured displacements, seepage pressures and forces in applied reinforcing structures were used for training and testing of RBF neural network. Gao (2010) combined two methods for the prediction of landslide

30 movements: the trend of time series was extracted by Grey System while the deviations from trend were approximated by the newly developed Evolutionary Neural Network. Similarly, Li et al. (2012) compared grey system theory and back propagation neural network (BPNN) to predict Jinlong ditch landslide deformation. Ran et al. (2010) adopted the genetic algorithm to optimize the architectural parameter of BPNN and improved the Sigmoid function. In this way they effectively reduced the probability to get into the local minima while employing neural networks to forecast the landslide deformation 
Nat. Hazards Earth Syst. Sci. Discuss., https://doi.org/10.5194/nhess-2017-253

Manuscript under review for journal Nat. Hazards Earth Syst. Sci.

Discussion started: 13 July 2017

(c) Author(s) 2017. CC BY 4.0 License.

and promoted the forecast precision. Chen Y et al. (2012) showed that Modular Neural Networks (MNN) perform better for the prediction of landslide movements than more simple ANN. Chen and Zeng (2013) used the BPNN in the combination of genetic algorithm and simulated annealing algorithm to optimize the weights and biases of the network. Such approach was shown to enhance the learning rate and improve the predicting precision. Lian et al. (2012a), Lian et al. (2012b) divided total

5 accumulative displacement of landslide into the trend component and the periodic component, according to the response relation between dynamic changes of landslide displacement and inducing factors. For the prediction of landslide displacements, a novel ANN technique called Ensemble of extreme learning machine (E-ELM) was used. In their next paper (Lian et al. 2013) an enhanced learning procedure Modified ensemble empirical mode decomposition (M-EEMD) was used and showed consistently better results. Chen HQ et al. (2012) reported the successful use of Jordan net type of Recurrent

10 Neural Network (RNN) to reproduce the movements of Baishuihe landslide on the south bank of Yangtze river 56 km away from Three Gorges dam. Also Yao et al. (2015) suggest that the use of RNN for dynamic processes as landslides should be preferred over static feed-forward neural networks. Moreover, they proposed using interpolation technique in order to enrich the training database. Chen et al. (2015) have also compared different machine learning strategies for the prediction of landslide displacements: General functional networks, Associativity functional networks and BPNN were used to forecast

15 the same case history. General functional networks were found to perform consistently better than other approaches.

From this review it can be seen that a lot of research effort is used in order to find the most promising machine learning algorithm. There are less reports on the optimum selection of input parameters, which is probably to the fact that this is very site specific.

In our study, two case histories of rainfall induced landslides are presented and analysed: Macesnik earthflow in Northern

20 Slovenia and Ventnor Undercliff landslide in the Isle of Wight, UK. These two landslides are very different in nature. Macesnik earthflow moved with the average rate of over $100 \mathrm{~mm} /$ day whereas the Ventnor Undercliff landslide is very slow ( $5 \mathrm{~mm} /$ year on average). Simple multi-layer feed-forward artificial neural networks were employed as the approximators of unknown functional relation between landslide movements and precipitations.

\section{Methods}

\section{$25 \quad 2.1$ Selection of input parameters}

In most cases, landslides and earthflows exhibit displacement rates that depend on rainfall and groundwater conditions. Rainfall and displacements are the parameters that are usually monitored and available for earth masses in motion that present a threat to human lives, infrastructure and properties. Some other parameters as e.g. temperature and evapotranspiration may play an important role for the changes in the rate of landslide movements, especially in cases of

30 shallow processes. Depending on each specific case other factors that influence the rate of landslide movements can be considered, e.g. landslide area and depth, slope inclination. 
Nat. Hazards Earth Syst. Sci. Discuss., https://doi.org/10.5194/nhess-2017-253

Manuscript under review for journal Nat. Hazards Earth Syst. Sci.

Discussion started: 13 July 2017

(c) Author(s) 2017. CC BY 4.0 License.

(c) (i)

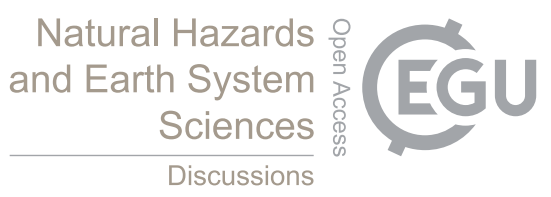

Both our cases can be described as deep-seated landslides with constant area and depth during the observation period. Neither human activities, nor earthquakes play any important role on the landslide movements or act as triggers of both landslides. Therefore, rainfall data and data on previous movements were used as input, while current displacement or rate of displacement was selected as output parameter.

\section{$5 \quad 2.2$ Displacement and rainfall measurements}

\subsubsection{Macesnik landslide}

Surface movements were monitored geodetically in ten cross sections. Each cross section had different length due to different width of the earthflow and consisted of 4 to 13 geodetic points. Only the point with the highest intensity of earthflow movements in individual cross-section was considered for the analysis. The repetitive geodetic measurements began on 2000-11-13 and continued until 2003-12-13. They were performed once a month except during the first period (2000-11-13 to 2001-2-21) where measurements were taken each 10 days. The profiles 1, 4, 5, 6, 8 and 9 (see Fig. 1) were monitored from the beginning while other were added subsequently. All ten profiles were installed and observed from 20017-23 on.

Local precipitations were measured by the rainfall gauging station in the Solčava village, approximately $1 \mathrm{~km}$ away from the 15 toe of the earthflow.

From February to August 2003 deep drainage trenches and drainage shafts were made between measuring sections 6 and 10 in order to stabilize the landslide. More details on the landslide and its rehabilitation can be found in Mikoš et al. (2005).

\subsubsection{Ventnor Undercliff landslide}

Extensive network of survey markers, piezometers, settlement cells and crack-meters to monitor ground movement is 20 maintained at the Undercliff landslide.

For the present study, the precise crack-meter data from Newport road (see Fig. 7) were used together with rainfall data which is also measured daily within the landslide area.

Vibrating wire crackmeters were used for precise monitoring of movements. Readings were taken repetitively and collected by datalogger in intervals of 3 hours (Carey, 2011). The data set from 1995 to 2004 was available for this study. The more

25 detailed description of the sensor, its installation and analyses of measurements are given in Carey (2011).

\subsection{Multi-layer feed-forward artificial neural network}

The motivation for the early development of artificial neural networks (ANN) was the study of the structure and processes in human brain. The ANN is a mathematical formulation that simulates the processes between neurons in human brain. In both, the ANN and the human brain neurons are interconnected. Similarly to a human brain, ANN has to be taught or trained. In our work, supervised learning was used, in which a set of input and output data are known and where the ANN learns the 
Nat. Hazards Earth Syst. Sci. Discuss., https://doi.org/10.5194/nhess-2017-253

Manuscript under review for journal Nat. Hazards Earth Syst. Sci.

Discussion started: 13 July 2017

(c) Author(s) 2017. CC BY 4.0 License.

correct answers. ANN is a network of simple units (neurons) operating locally. Each unit receives signals from other units, which are reduced or amplified, and then processes these signals and transmits them to further units. There are several types of ANN geometry. A review of different ANNs is given in several papers, books and internet sites (e.g. Lippmann, 1987; Sarle, 2002; Samarasinghe, 2007). Usually, if functional approximation is sought, the multi-layer feed-forward network is chosen. Since it is our aim to estimate the earthflow/landslide movements, the multi-layer feed-forward network trained by the supervised learning was chosen in this research.

The geometry of a multi-layer feed-forward neural network is shown in Figure 2. Input units (neurons) are connected to the first layer of hidden units that are further connected to the units of the second hidden layer. The units of the last hidden layer are connected to the output units. The multi-layer feed-forward networks are usually employed as the approximators of the

10 unknown functional relation.

The input units represent the input data, and the output units represent the output data. During the training process, weights of all connections and threshold values of neuron's activation function are obtained by error back propagation algorithm in such a way that ANN approximates the function between input and output values for training data set. More detailed description of ANN and learning process is given e.g. in Mayoraz and Vulliet (2002).

\section{$15 \quad 3$ Results and discussion}

\subsection{Macesnik landslide}

The Macesnik landslide in Northern Slovenia is one of the major landslides in Slovenia. It was triggered in 1989 above the Solčava village (Horvat and Galič, 1998) on the southern slopes of Olševa mountain. In the period between 1994 and 1998 , the landslide enlarged, partially retrogressively, but mostly progressively down the slope as earthflow. It gradually reached

20 the length of 2,400 m having the width between 40 and $200 \mathrm{~m}$. The front of the earthflow stopped in 2001 at the limestone outcrop conveniently located in the predominantly carboniferous soft rock formations to protect the Solčava village. The total area affected by the earthflow is estimated to 20 ha and its thickness from 8 to $25 \mathrm{~m}$. The volume of the earthflow amounts to 2.5 million $\mathrm{m}^{3}$ (Majes et al. 2004a, 2004b; Mikoš et al. 2005). The slope inclination ranges from $10.2^{\circ}$ at the top to $15.6^{\circ}$ at the bottom of the earthflow.

25 Figs. 3 and 4 present the measured monthly and cumulative precipitations and observed resulting movements of individual cross sections from November 2000 to December 2003, respectively. Table 1 gives the overview of minimum, maximum and average rate of movements and accumulated total movements for selected measuring profiles in the central part of the landslide for the same time period.

Several combinations of data that presented input-output pairs for training and testing the performance of ANN were tried.

30 Details on this results can be found in Logar et al. (2009). The ANN gave best results with the following input-output sets of data:

8 input variables: 
Nat. Hazards Earth Syst. Sci. Discuss., https://doi.org/10.5194/nhess-2017-253

Manuscript under review for journal Nat. Hazards Earth Syst. Sci.

Discussion started: 13 July 2017

(c) Author(s) 2017. CC BY 4.0 License.

- cumulative amount of rainfall for 90 days $\left(w_{90}\right)$,

- cumulative amount of rainfall for 10 days $\left(w_{10}\right)$,

- cumulative amount of rainfall for 5 days $\left(w_{5}\right)$,

- components of rate of displacement in previous month $\left(v_{y 0}, v_{x 0}, v_{H 0}\right)$,

- rate of displacement in horizontal plane in previous month $\left(v_{y x 0}\right)$,

- $\quad$ rate of spatial displacement in previous month $\left(v_{y \times H O}\right)$.

5 output variables:

- components of rate of displacement for next month $\left(v_{y}, v_{x}, v_{H}\right)$,

- rate of displacement in horizontal plane for next month $\left(v_{y x}\right)$,

- $\quad$ rate of spatial displacement for next month $\left(v_{y x H}\right)$.

Subscripts $y, x$ and $H$ refer to East-West, North-South and height coordinates of the national coordinate system, respectively. It was interesting to note that even though 2 output variables are obviously calculated from other 3 (same is valid for respective input variables) this repeated information to neural network considerably improved the performance of trained ANN. This is in a way similar to the interpolation of additional training sets used by Yao et al. (2015) only that in our case

15 we strictly used only measured values.

Two sets of training were performed. Firstly, only measured data were used (denoted as "ANN" in figures). Secondly, one additional data point was inserted that was not measured but it is obvious: if there is no rain and no previous movements (all input data equal to 0 ) the expected rate of movement is also 0 . The results obtained with this additional information is denoted by “ANN+0" in graphs with results.

20 Different ANN geometries were initially used in training procedure. One or two hidden layers were used with 10 to 30 neurones in each layer. The presented results are obtained with neural network with two hidden layers each having 25 neurones.

Twenty seven series of measurements were available for the Macesnik landslide. In all examples the ANN was trained on a selected number of input-output pairs from the beginning of measurements. First training was performed with first 14 inputoutput pairs, then the displacements at the time of $15^{\text {th }}$ and $16^{\text {th }}$ measurement were predicted by ANN. In the next step, ANN was trained on the set of first 16 input output pairs and ANN predicted the displacements at the $17^{\text {th }}$ and $18^{\text {th }}$ measurements, etc. This procedure was repeated until February 2003 when construction works started for the installation of deep drainage trench. After that the conditions on site were changed and previous "knowledge" on the earthflow behaviour could not be used any more. Such a stepwise training procedure simulated the possible use of ANN in decision making process. In real

30 situations, all available past measurements would be used for training. Prediction of landslide movements would then be made either by using the forecast rainfall or for a parametric study of different rainfall scenarios.

The results for the rate of horizontal displacement $v_{x y}$ is presented in Fig. 5. Two breaks in graph are consequence of reinstallation of geodetic points due to large displacements of the earthflow. To obtain the results of ANN after the new zero 
Nat. Hazards Earth Syst. Sci. Discuss., https://doi.org/10.5194/nhess-2017-253

Manuscript under review for journal Nat. Hazards Earth Syst. Sci.

Discussion started: 13 July 2017

(c) Author(s) 2017. CC BY 4.0 License.

readings, the predicted rates of displacements from ANN itself were used. From the results in Fig. 5 one can observe the considerable influence of additional information used in second training set "ANN+0". Fig. 6 compares the measured displacements with those obtained from ANN predictions but includes also the period after the initiation of remediation works. The agreement is very good until the start of works. After February 2003 the measured and predicted displacements start to deviate. There are two reasons for such result: (i) the ANN was not trained additionally with new data and more important (ii) extensive earthworks caused additional displacements during the construction period whereas after the installation of the drainage trench the conditions on site changed considerably. By comparing both curves in Fig. 6 we can observe exactly the expected behaviour. During remediation works the ANN prediction is below measured values since it was done in relatively dry period but additional movements were caused by excavations. After the works were completed, the ANN prediction suggests what would have occurred if there hadn't been a drainage trench installed.

\subsection{Ventnor Undercliff landslide}

The Isle of Wight (UK) Undercliff is the largest urban landslide complex in north-western Europe and has been studied extensively by the local authorities on the Isle of Wight as well as by the UK Department of the Environment (Marsden et al. 2009). Ventnor is the main town within the Undercliff with a population of 6,500 whilst approximately 12,000 residents in total live in the Undercliff. The Ventnor Undercliff landslide complex was activated as a result of aggressive coastal erosion following a rise in sea levels after the last ice age about 10,000 years ago. Slow intermittent ground movements in the vicinity of the town of Ventnor have resulted in extensive damage to property and services over the last 200 years.

Field monitoring of ground movements, water levels and weather events is constantly carried out. Records of ground movements were recognised as being important in understanding ground behaviour. This information is collected in the form

20 of an integrated geographical information system.

For our work we used the daily displacement measurements monitored by crackmeter on Newport Road, situated near the city of Ventnor (Fig. 7), and the daily rainfall data measured within the studied area. The data for the period from December 1995 to September 2004 were available but there are some gaps due to technical reasons (see Fig. 8). The total displacements, maximum, minimum and average rates of movements are given in Table 2. The rainfall data are available

25 continuously from March 1992 to August 2004. For this study we decided to use displacement and rainfall data from 1 September 2000 to 30 June 2001 (Fig. 8 and Fig. 9, respectively) where changes in displacement rate were observed. For this period the complete set of data for training consisted of 272 points, one for each day.

For the Undercliff landslide a very simple configuration of ANN was used: 3 to 5 input neurons, 10 neurons in single hidden layer and 1 output neuron (Fig. 10). Three different input-output sets were used and compared. In first case (denoted as 30 ANN3), 3 input parameters were: cumulative amount of rainfall for 10, 30 and 90 days (Rain 10, Rain 30 and Rain 90 , respectively). The only output variable was displacement for the next 10 days (Displacement). In second case (ANN4), accumulated displacements in the last 90 days (Displace 90) was added as the fourth input parameter. In third case (ANN5) accumulated displacements in the last 30 days (Displace 30 ) was used as fifth input parameter. 
Nat. Hazards Earth Syst. Sci. Discuss., https://doi.org/10.5194/nhess-2017-253

Manuscript under review for journal Nat. Hazards Earth Syst. Sci.

Discussion started: 13 July 2017

(c) Author(s) 2017. CC BY 4.0 License.

(c) (i)

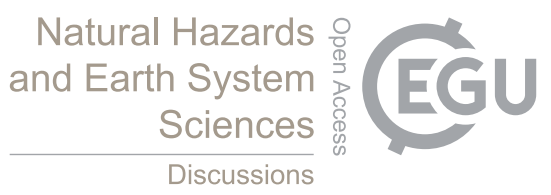

The training and testing principle was the following (see also Fig. 11):

- training the ANN with data for 6 months from September 2000 to February 2001 - test on data from March 2001,

- training the ANN with data for 7 months from September 2000 to March 2001 - test on data from April 2001,

- $\quad$ similarly, two more steps were made to get the results also for May and June 2001.

5 The results obtained for individual months and for all three alternatives of input-output parameters are presented together with measured data in Fig. 12. The correspondence between measurements and ANN predictions depends on the selection of input data (ANN5 in our case). Again, a very good result can be obtained when the suitable set of input-output parameters is found.

In this case, daily data were available and therefore considerably larger data base for training of ANN. As a result, very good prediction was obtained with a simple ANN geometry.

\section{Conclusion}

The feed forward artificial neural network (ANN) was used to correlate the observed movements and rainfall data for two very different slope instability phenomena. It was shown that trained ANN is able to accurately model the particular landslide movements if adequately long series of reliable data on rainfall and displacements are available and optimum combination of input - output data together with suitable ANN architecture is found.

Therefore, it is possible to make the predictions of landslide behaviour on the basis of previous observations and weather forecast. Such tool can be a valuable decision support system for civil protection body and/or stakeholders responsible for the population and properties in the risk area.

In such a way, the ANN is an alternative to the mathematical models which are mostly used for the assessment of the landslide behaviour. Mathematical models have to take into account very simplified ground conditions and underground water conditions with respect to the reality but rely on sound physical knowledge. On the other hand, ANN is a "black box" but uses site specific measured input data without any further assumptions.

In this study it was also shown that the repetition of data within training data sets has a positive effect on the results. Similarly, whenever possible, the training data set should include obvious and/or theoretically justified input sets.

Acknowledgments. Part of this research was conducted in the framework of FRANE research project financed by European Commission - Communications and Civil Protection, Unit A5. Authors wish to express thanks to Diego Maccieri who performed the ANN calculations for Undercliff landslide. 
Nat. Hazards Earth Syst. Sci. Discuss., https://doi.org/10.5194/nhess-2017-253

Manuscript under review for journal Nat. Hazards Earth Syst. Sci.

Discussion started: 13 July 2017

(c) Author(s) 2017. CC BY 4.0 License.

\section{References}

Alimohammadlou, Y., Najafi, A., and Gokceoglu, C.: Estimation of rainfall-induced landslides using ANN and fuzzy clustering methods: A case study in Saeen Slope, Azerbaijan province, Iran, Catena, 120, 149-162, doi:10.1016/j.catena.2014.04.009, 2014.

5 Carey, J.M.: The Progressive Development and Post-failure Behaviour of Deep-seated Landslide Complexes, Durham theses, Durham University, Available at Durham E-Theses Online, http://etheses.dur.ac.uk/3186/, 2011.

Chen, H.Q., Zeng, Z.G., and Tang, H.M.: Study on landslide deformation prediction based on recurrent neural network under the function of rainfall, in: Huang, T.W. et al. (Eds.), ICONIP 2012, Part IV, LNCS 7666, pp. 683-690, doi:10.1007/978-3642-34478-7_83, 2012.

10 Chen, H.Q., and Zeng, Z.G.: Deformation Prediction of Landslide Based on Improved Back-propagation Neural Network, Cogn. Comput., 5(1), 56-62, doi:10.1007/s12559-012-9148-1, 2013.

Chen, J., Zeng, Z., Jiang, P., and Tang, H.: Deformation prediction of landslide based on functional network, Neurocomputing, 149, 151-157, doi:10.1016/j.neucom.2013.10.044, 2015.

Chen, Y., Wang, S., Chen, N., Long, X., and Tang, X.: Forecasting Cohesionless Soil Highway Slope Displacement Using

15 Modular Neural Network, Discrete Dynamics in Nature and Society, Volume 2012, Article ID 504574, 15 pages, Hindawi Publishing Corporation, doi:10.1155/2012/504574, 2012.

Conforti, M., Pascale, S., Robustelli, G., and Sdao, F.: Evaluation of prediction capability of the artificial neural networks for mapping landslide susceptibility in the Turbolo River catchment (northern Calabria, Italy), Catena, 113, 236-250, doi:10.1016/j.catena.2013.08.006, 2014.

20 Dou, J., Yamagishi, H., Pourghasemi, H.R., Yunus, A.P., Song, X., Xu, Y., and Zhu, Z.: An integrated artificial neural network model for the landslide susceptibility assessment of Osado Island, Japan, Nat. Hazards, 78, 1749-1776, doi:10.1007/s11069-015-1799-2, 2015.

Ermini, L., Catani, F., and Casagli, N.: Artificial Neural Networks applied to landslide susceptibility assessment, Geomorphology, 66, 327-343, doi:10.1016/j.geomorph.2004.09.025, 2005.

25 Gao, W.: Prediction of Landslide Based on Grey System and Evolutionary Artificial Neural Networks, in: International Conference on System Science, Engineering Design and Manufacturing Informatization - Volume 02, pp. 64-67, doi:10.1109/ICSEM.2010.106, 2010.

Gelisli, K., Kaya, T., and Babacan, A.E.: Assessing the factor of safety using an artificial neural network: case studies on landslides in Giresun, Turkey, Environ. Earth Sci., 73, 8639-8646, doi:10.1007/s12665-015-4027-1, 2015.

30 Goetz, J.N., Brenning, A., Petschko, H., and Leopold, P.: Evaluating machine learning and statistical prediction techniques for landslide susceptibility modelling, Comput. Geosci., 81, 1-11, doi:10.1016/j.cageo.2015.04.007, 2015.

Horvat, A., and Galič, R.: Sanacija Macesnikovega plazu pod Olševo = Rehabilitation of landslide near the Macesnik farm below Olševa, Ujma, 12, 179-181, 1998. 
Nat. Hazards Earth Syst. Sci. Discuss., https://doi.org/10.5194/nhess-2017-253

Manuscript under review for journal Nat. Hazards Earth Syst. Sci.

Discussion started: 13 July 2017

(c) Author(s) 2017. CC BY 4.0 License.

Lacasse, S.: Protecting society from landslides - the role of the geotechnical engineer, $8^{\text {th }}$ Terzaghi Oration, in: Proceedings of the $18^{\text {th }}$ International Conference on Soil Mechanics and Geotechnical Engineering, Paris 2013, Vol. 1, pp. 15-34, 2013. Li, R.Y., Ruan, Y.F., Li, S.S., and Wu, Y.H.: Study on Deformation Prediction of Landslide Based on Grey Theory and BP Neural Network, Applied Mechanics and Materials, 204-208, 520-525, doi:10.4028/www.scientific.net/AMM.204-208.520, 52012.

Li, C., Tang, H., Ge, Y., Hu, X., and Wang, L.: Application of back-propagation neural network on bank destruction forecasting for accumulative landslides in the three Gorges Reservoir Region, China, Stoch. Environ. Res. Risk Assess., 28, 1465-1477, doi:10.1007/s00477-014-0848-9, 2014.

Lian, C., Zeng, Z., Yao, W., and Tang, H.: Displacement Prediction Model of Landslide Based on Ensemble of Extreme

10 Learning Machine, in: Huang, T.W. et al. (Eds), ICONIP 2012, Part IV, LNCS 7666, pp. 240-247, doi:10.1007/978-3-64234478-7_30, 2012a.

Lian, C., Zeng, Z., Yao, W., and Tang, H.: Displacement prediction model of landslide based on a modified ensemble empirical mode decomposition and extreme learning machine, Nat. Hazards, 66(2), 759-771, doi:10.1007/s11069-012-05176, 2012b.

15 Lian, C., Zeng, Z., Yao, W., and Tang, H.: Ensemble of extreme learning machine for landslide displacement prediction based on time series analysis, Neural Comput. Applic., 24(1), 99-107, doi:10.1007/s00521-013-1446-3, 2013.

Lian, C., Zeng, Z., Yao, W., and Tang, H.: Multiple neural networks switched prediction for landslide displacement, Engineering Geology, 186, 91-99, doi:10.1016/j.enggeo.2014.11.014, 2015.

Lippmann, R.P.: An Introduction to Computing with Neural Nets, IEEE ASSP Mag., 4(2), 4-22, 1987.

20 Logar, J., Turk, G., and Ambrožič, T.: Artificial neural network modelling of landslide movements, in: Future Risk Assessment as a New European approach to landslide hazards, Communications and Civil Protection, Unit A5, pp. 215-235, 2009.

Lu, P., and Rosenbaum, M.S.: Artificial neural networks and Grey Systems for the prediction of slope stability, Nat. Hazards, 30(3), 383-398, doi:10.1023/B:NHAZ.0000007168.00673.27, 2003.

25 Majes, B., Robas, A., Žigman, F., and Petkovšek, A.: Macesnikov plaz včeraj, danes in jutri = Macesnik landslide yesterday, today and tomorrow, in: Razprave četrtega posvetovanja slovenskih geotehnikov, Rogaška Slatina, 9.-11. June 2004, Slovenian Geotechnical Society, pp. 323-338, (In Slovene, English Summary), 2004.

Majes, B., Žigman, F., Fazarinc, R., Mikoš, M., Robas, A., and Petkovšek, A.: Investigations and mitigation of the Macesnik landslide in Slovenia, in: Abstracts of the Contributions of the European Geosciences Union General Assembly 2004, EGU

30 General Assembly 2004, Katlenburg-Lindau, Geophysical Research Abstracts, Vol. 6, pp. 1-2, 2004.

Marsden, P., Fairbank, H., and Houghton, J.: Geotechnical study area G1 - Ventnor Undercliff landslide complex - an overview, Isle of Wight, UK, in: Future Risk Assessment as a New European approach to landslide hazards, Communications and Civil Protection, Unit A5, 2009. 
Nat. Hazards Earth Syst. Sci. Discuss., https://doi.org/10.5194/nhess-2017-253

Manuscript under review for journal Nat. Hazards Earth Syst. Sci.

Discussion started: 13 July 2017

(c) Author(s) 2017. CC BY 4.0 License.

Mayoraz, F., Cornu, T., and Vulliet, L.: Using Neural Networks to Predict Slope Movements, in: Senneset, K. (Eds), Proc. $7^{\text {th }}$ Int. Symp. On Landslides, Trondheim, 17-21 June 1996, pp. 295-300, 1996.

Mayoraz, F., and Vulliet, L.: Neural Networks for Slope Movement Prediction, Int. J. Geomech., 2(2), 153-173, doi:10.1061/(ASCE)1532-3641(2002)2:2(153), 2002.

5 Mikoš, M., Fazarinc, R., Pulko, B., Petkovšek, A., and Majes, B.: Stepwise mitigation of the Macesnik landslide, N Slovenia, Nat. Hazards Earth Syst. Sci., 5, 948-958, doi:1684-9981/nhess/2005-5-947, 2005.

Nourani, V., Pradhan, B., Ghaffari, H., and Sharifi, S.S.: Landslide susceptibility mapping at Zonouz Plain, Iran using genetic programming and comparison with frequency ratio, logistic regression, and artificial neural network models, Nat. Hazards, 71, 523-547, doi:10.1007/s11069-013-0932-3, 2014.

10 Pradhan, B., Mansor, S., and Pirasteh, S.: Landslide Susceptibility Mapping: an Assessment of the Use of an Advanced Neural Network Model with Five Different Training Strategies, in: Chi Leung Patrick Hui (Eds.), Artificial Neural Networks - Application, ISBN: 978-953-307-188-6, InTech, 2011.

Pradhan, B., and Lee, S.: Landslide risk analysis using artificial neural network model focussing on different training sites, International Journal of Physical Sciences, 4(1), 1-15, 2009.

15 Ran, Y.F., Xiong, G.C., Li, S.S., and Ye, L.Y.: Study on deformation prediction of landslide based on genetic algorithm and improved BP neural network, Kybernetes, 39(8), 1245-1254, doi:10.1108/03684921011063529, 2010.

Samarasinghe, S.: Neural networks for applied sciences and engineering: from fundamentals to complex pattern recognition, Taylor \& Francis group, ISBN:978-1-4200-1306-1, 2007.

Sarle, W.S.: Neural Network FAQ, Periodic posting to the Usnet newsgroup comp.ai.neural-nets, URL:

20 ftp://ftp.sas.com/pub/neural/FAQ.html, 2002.

Thiebes, B., Bell, R., Glade, T., Jäger, S., Mayer, J., Anderson, M., and Holcombe, L.: Integration of a limit-equilibrium model into a landslide early warning system, Landslides, 11, 859-875, doi:10.1007/s10346-013-0416-2, 2014.

Wang, L.J., Guo, M., Sawada, K., Lin, J., and Zhang, J.: A comparative study of landslide susceptibility maps using logistic regression, frequency ratio, decision tree, weights of evidence and artificial neural network, Geosciences Journal, 20(1), 117-

25 136, doi:10.1007/s12303-015-0026-1, 2016.

Yao, W., Zeng, Z., Lian, C., and Tang, H.: Training enhanced reservoir computing predictor for landslide displacement, Engineering Geology, 188, 101-109, doi:10.1016/j.enggeo.2014.11.008, 2015.

Zeng, Y., Yan, E., Li, C.F., and Li, Y.: Application of Multivariable Time Series Based on RBF Neural Network in Prediction of Landslide Displacement, in: Jie, Z.J. et al. (Eds.), ICYCS 2008, pp. 2707-2712, doi:10.1109/ICYCS.2008.163, 302008. 
Nat. Hazards Earth Syst. Sci. Discuss., https://doi.org/10.5194/nhess-2017-253

Manuscript under review for journal Nat. Hazards Earth Syst. Sci.

Discussion started: 13 July 2017

(c) Author(s) 2017. CC BY 4.0 License.

(c) (1)

\section{Natural Hazards and Earth System Sciences \\ Discussions}

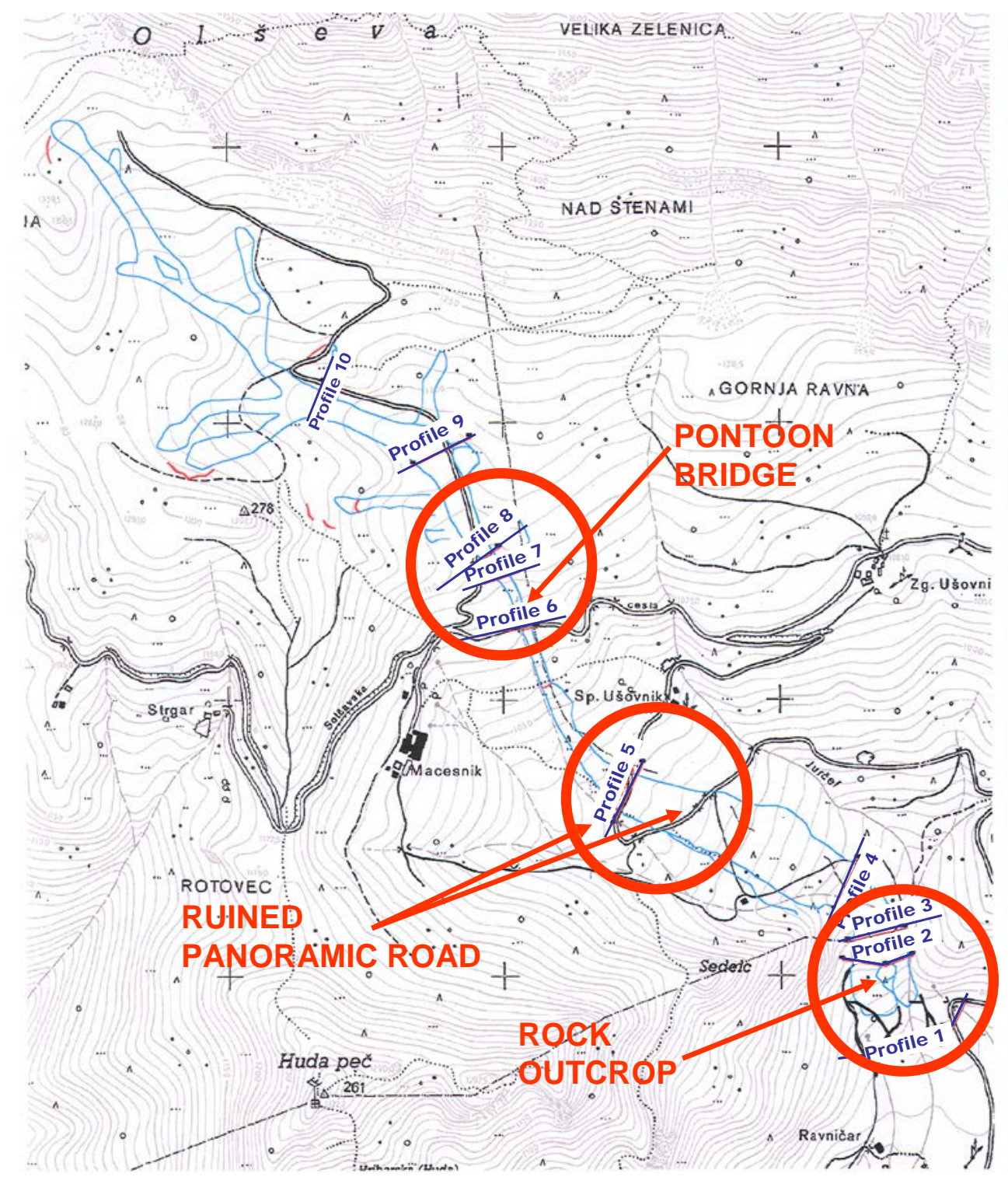

Figure 1: Plan view of Macesnik landslide. 
Nat. Hazards Earth Syst. Sci. Discuss., https://doi.org/10.5194/nhess-2017-253

Manuscript under review for journal Nat. Hazards Earth Syst. Sci.

Discussion started: 13 July 2017

(c) Author(s) 2017. CC BY 4.0 License.

(c) (1)

the $4^{\text {th }}$ neuron ill the $1^{\text {st }} \mathbb{l}$ idden layer

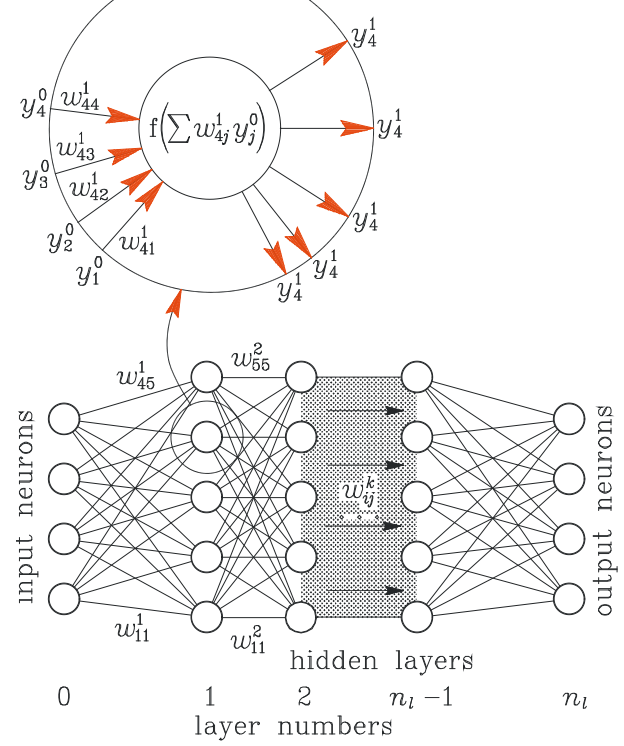

Figure 2: The geometry of a multi-layer feed-forward neural network.

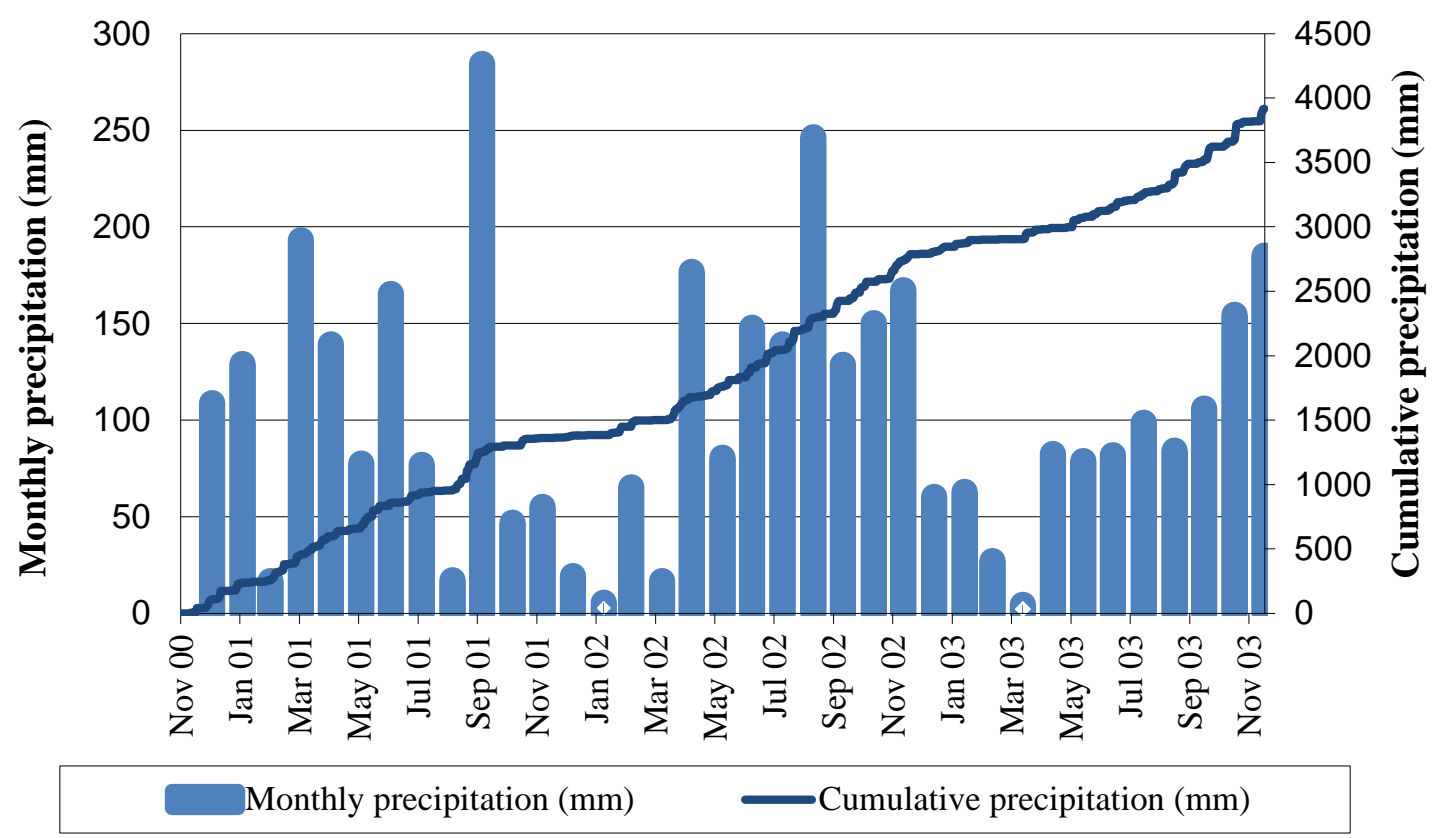

Figure 3: Measured precipitations at the Macesnik landslide from Oct 2000 to Dec 2003. 
Nat. Hazards Earth Syst. Sci. Discuss., https://doi.org/10.5194/nhess-2017-253

Manuscript under review for journal Nat. Hazards Earth Syst. Sci.

Discussion started: 13 July 2017

(c) Author(s) 2017. CC BY 4.0 License.

(c) (i)
Natural Hazards and Earth System

Sciences

Discussions

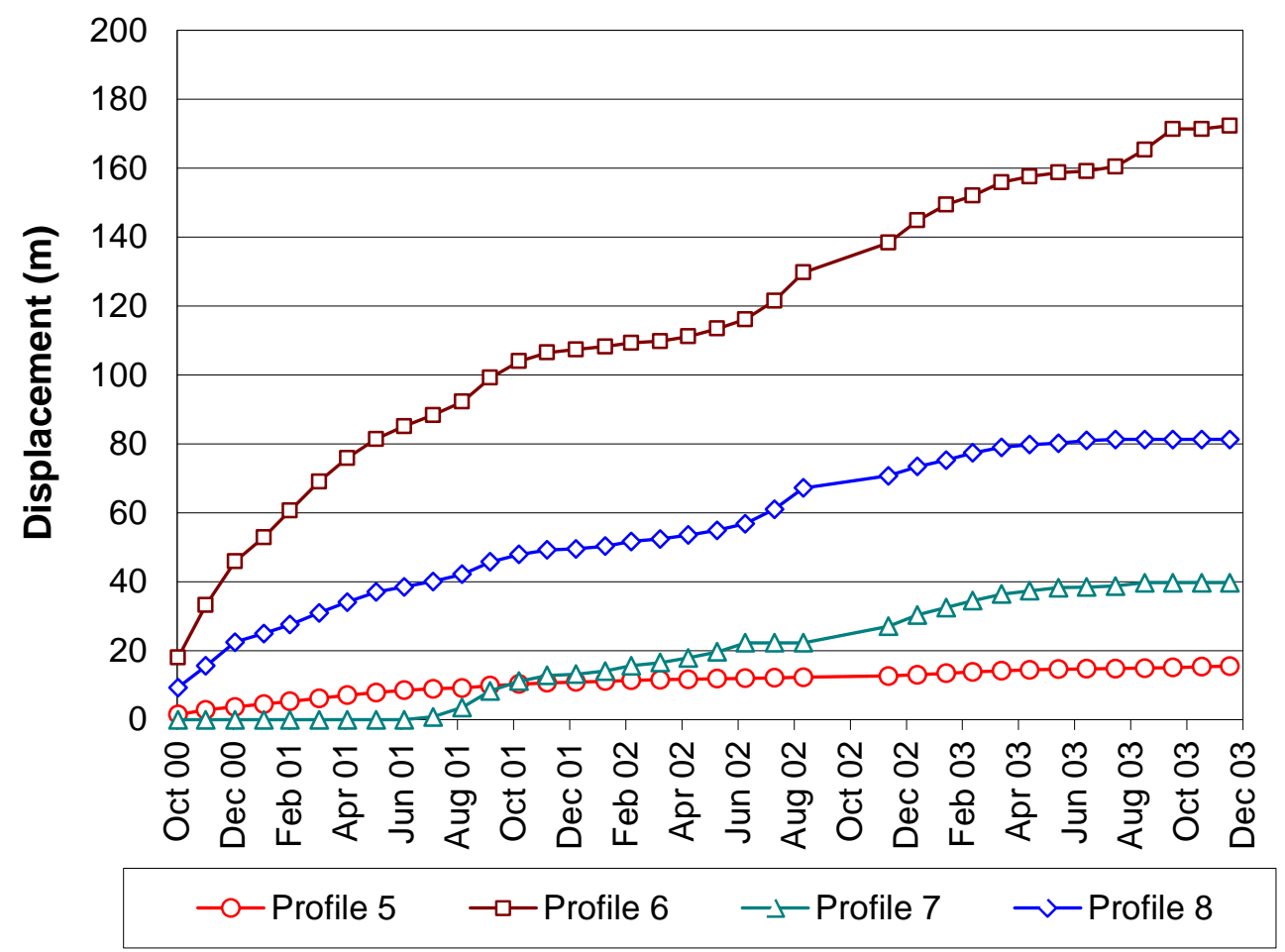

Figure 4: Measured displacements of Macesnik landslide from Oct 2000 to Dec 2003.

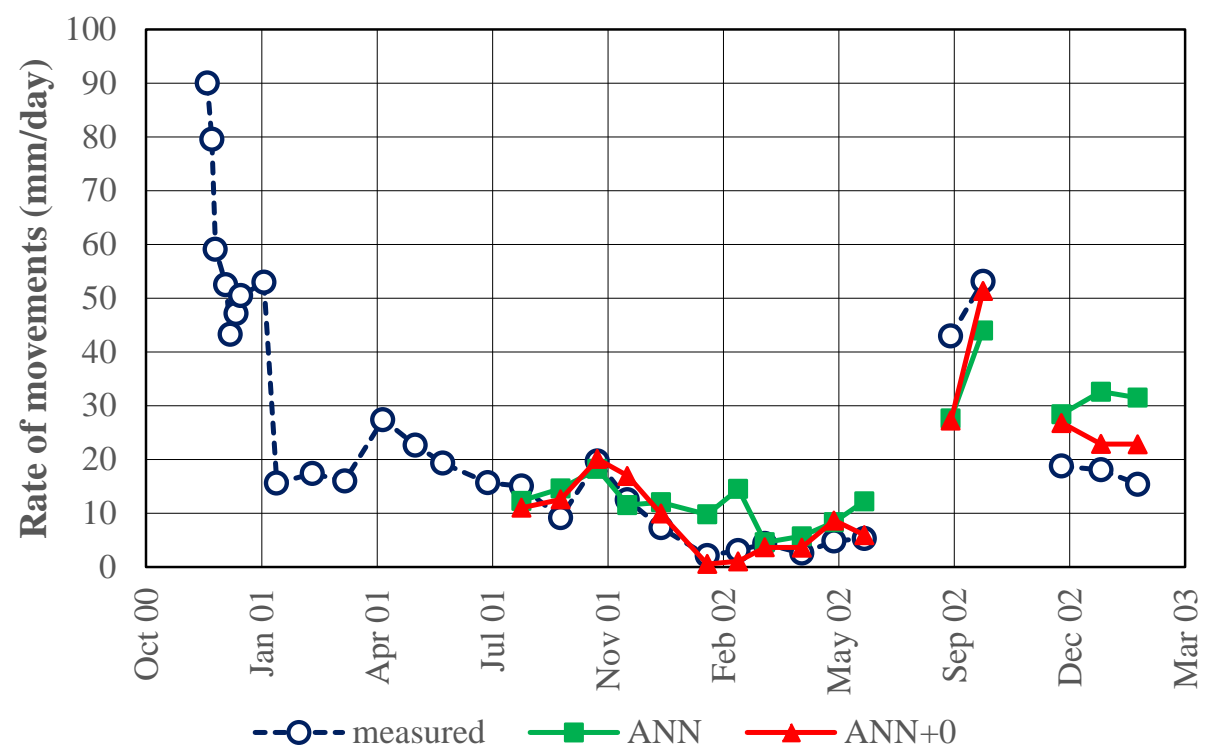

Figure 5: ANN predictions of the rate of horizontal movements - Macesnik earthflow. 
Nat. Hazards Earth Syst. Sci. Discuss., https://doi.org/10.5194/nhess-2017-253

Manuscript under review for journal Nat. Hazards Earth Syst. Sci.

Discussion started: 13 July 2017

(c) Author(s) 2017. CC BY 4.0 License.
Natural Hazards and Earth System Sciences

Discussions

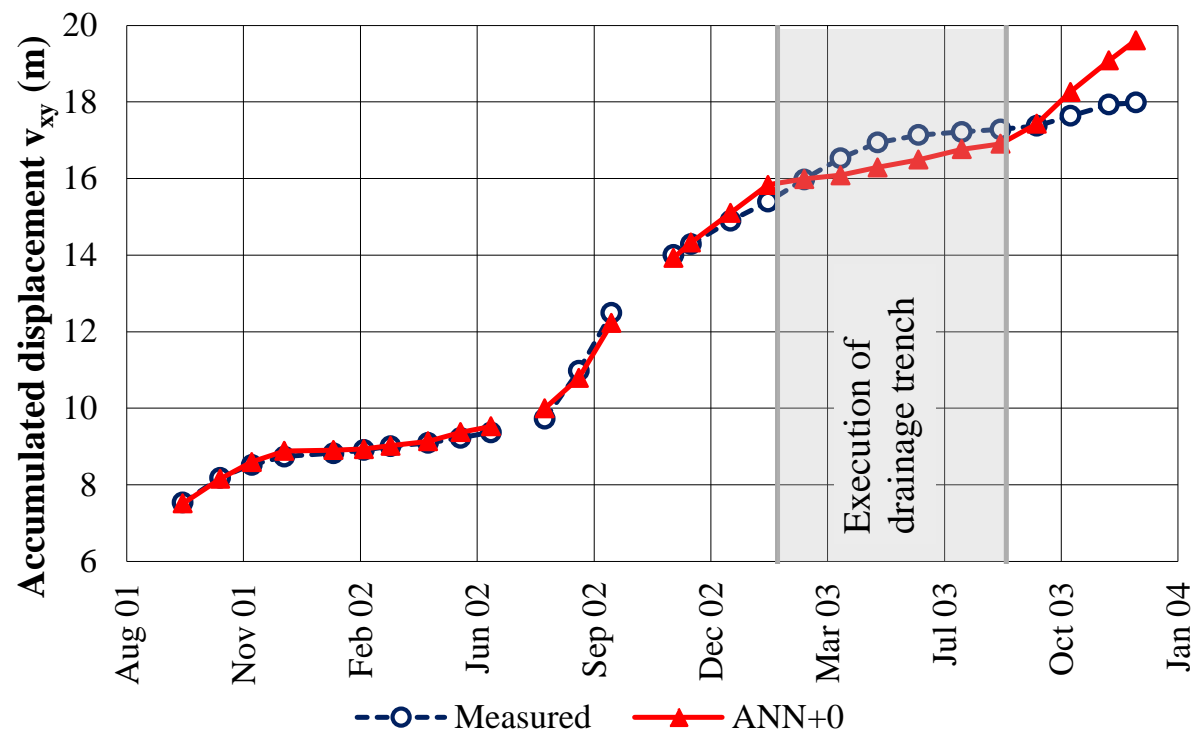

Figure 6: Calculated displacements based on ANN predictions of the rate of movements - Macesnik earthflow.

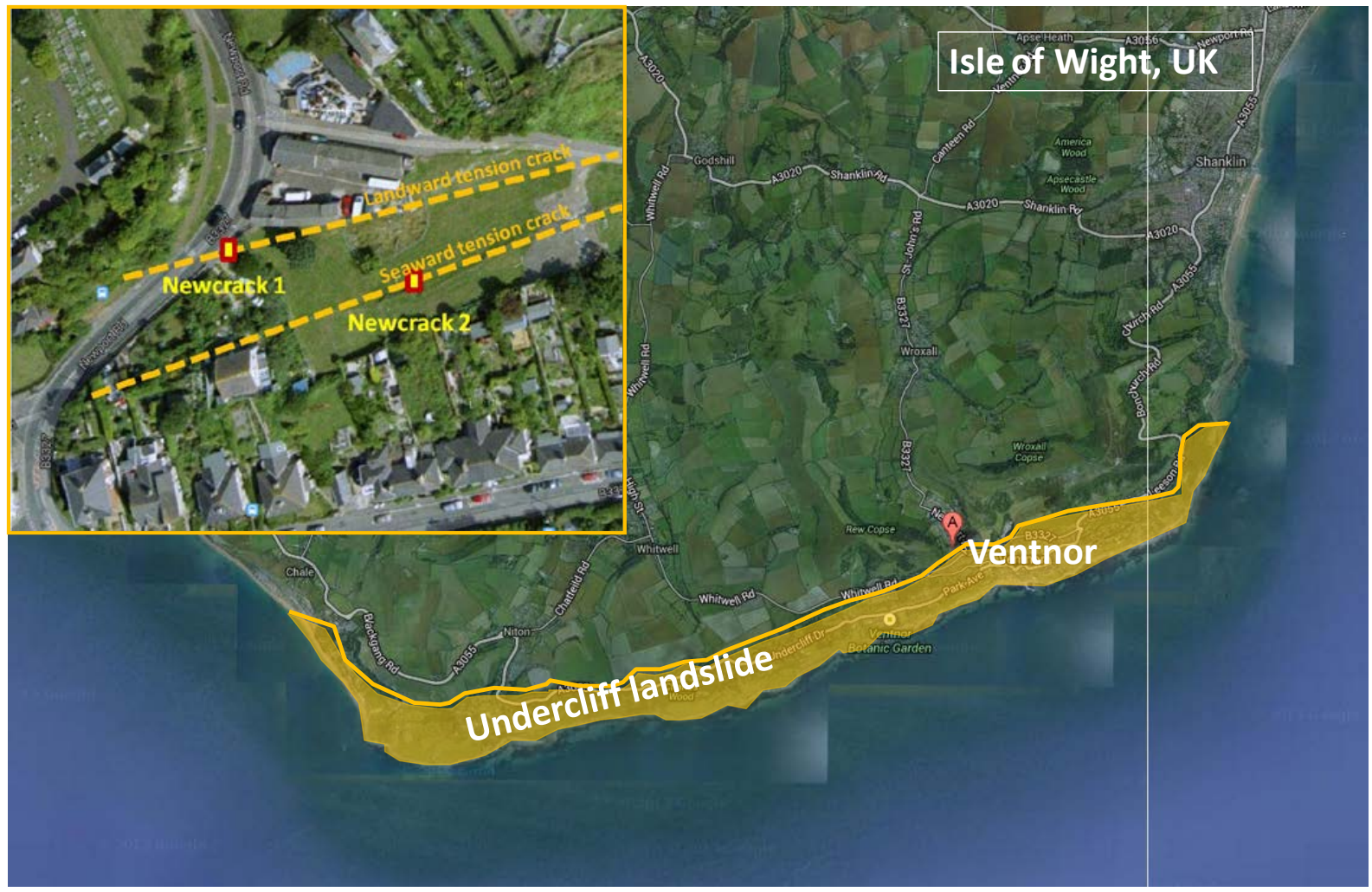

Figure 7: The layout of the Undercliff landslide and the position of crackmeters al location " $A$ ". 
Nat. Hazards Earth Syst. Sci. Discuss., https://doi.org/10.5194/nhess-2017-253

Manuscript under review for journal Nat. Hazards Earth Syst. Sci.

Discussion started: 13 July 2017

(c) Author(s) 2017. CC BY 4.0 License.
Natural Hazards and Earth System

Sciences

Discussions

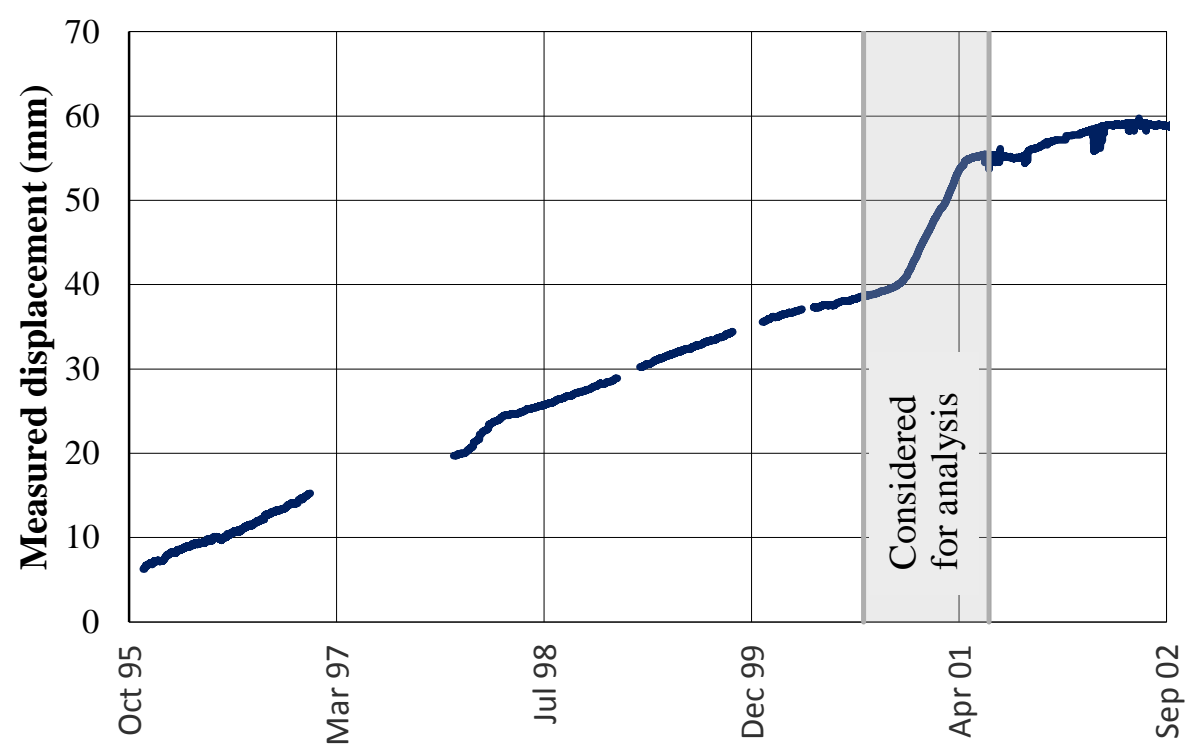

Figure 8: Cumulative displacements measured by Crackmeter 1 - Undercliff, Isle of Wight, UK.

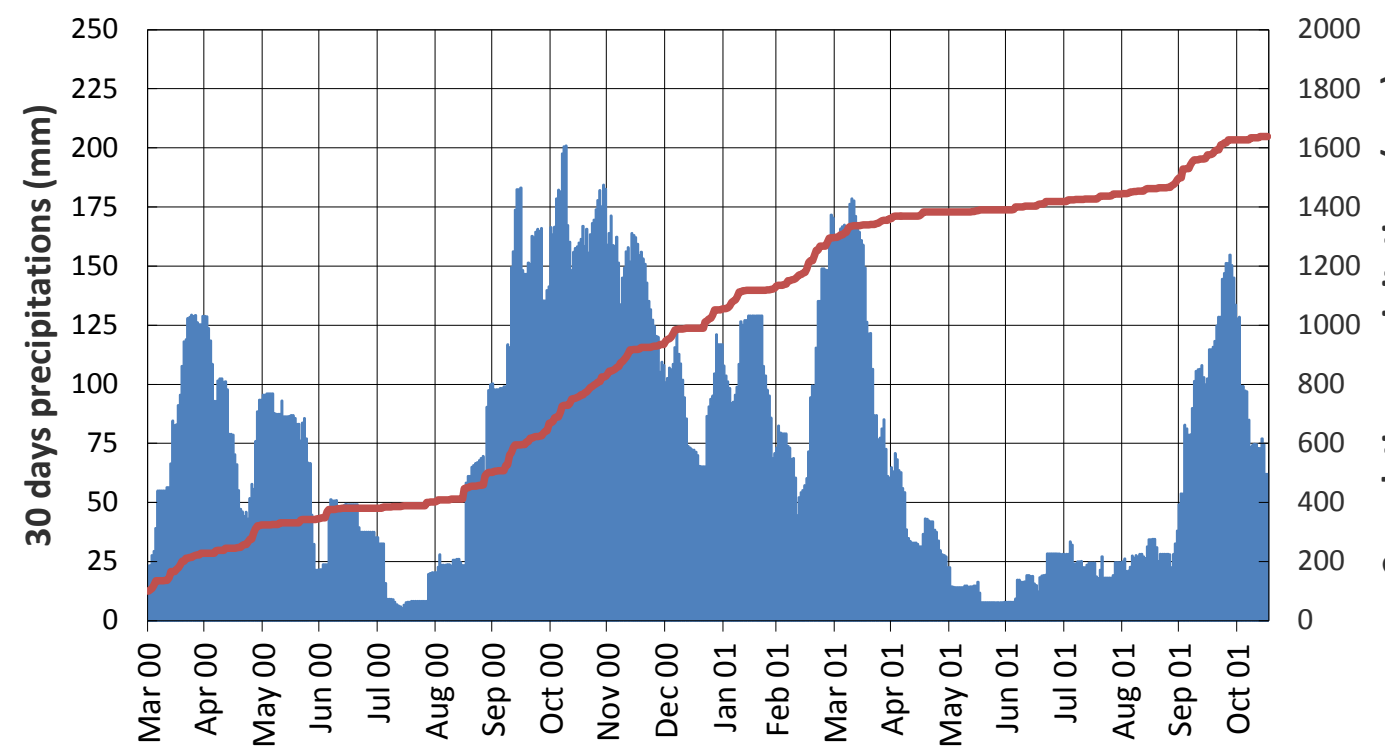

Figure 9: Precipitations - cumulative and for $\mathbf{3 0}$ day periods (Undercliff landslide). 
Nat. Hazards Earth Syst. Sci. Discuss., https://doi.org/10.5194/nhess-2017-253

Manuscript under review for journal Nat. Hazards Earth Syst. Sci.

Discussion started: 13 July 2017

(c) Author(s) 2017. CC BY 4.0 License.
Natural Hazards and Earth System Sciences

Discussions (C) (1)

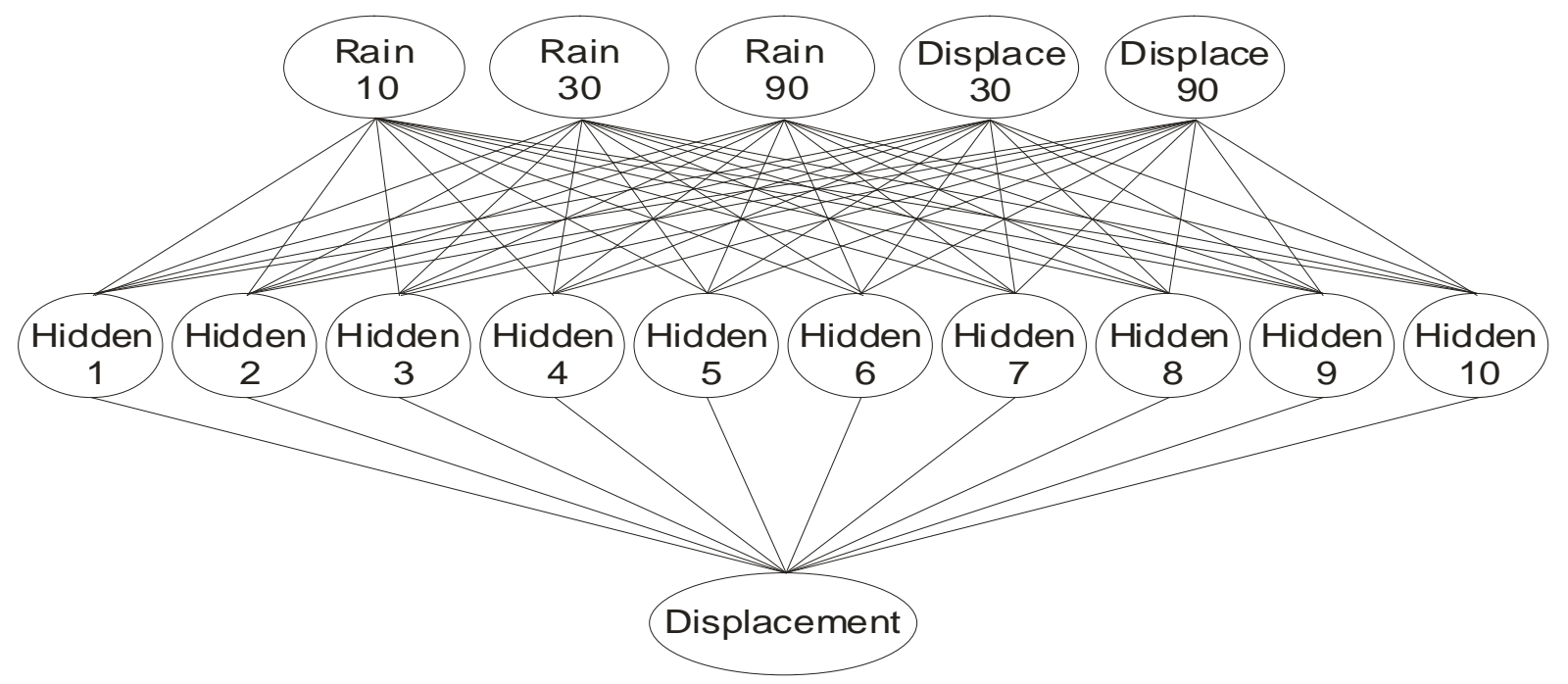

Figure 10: ANN architecture for the case ANN5 (Undercliff landslide).

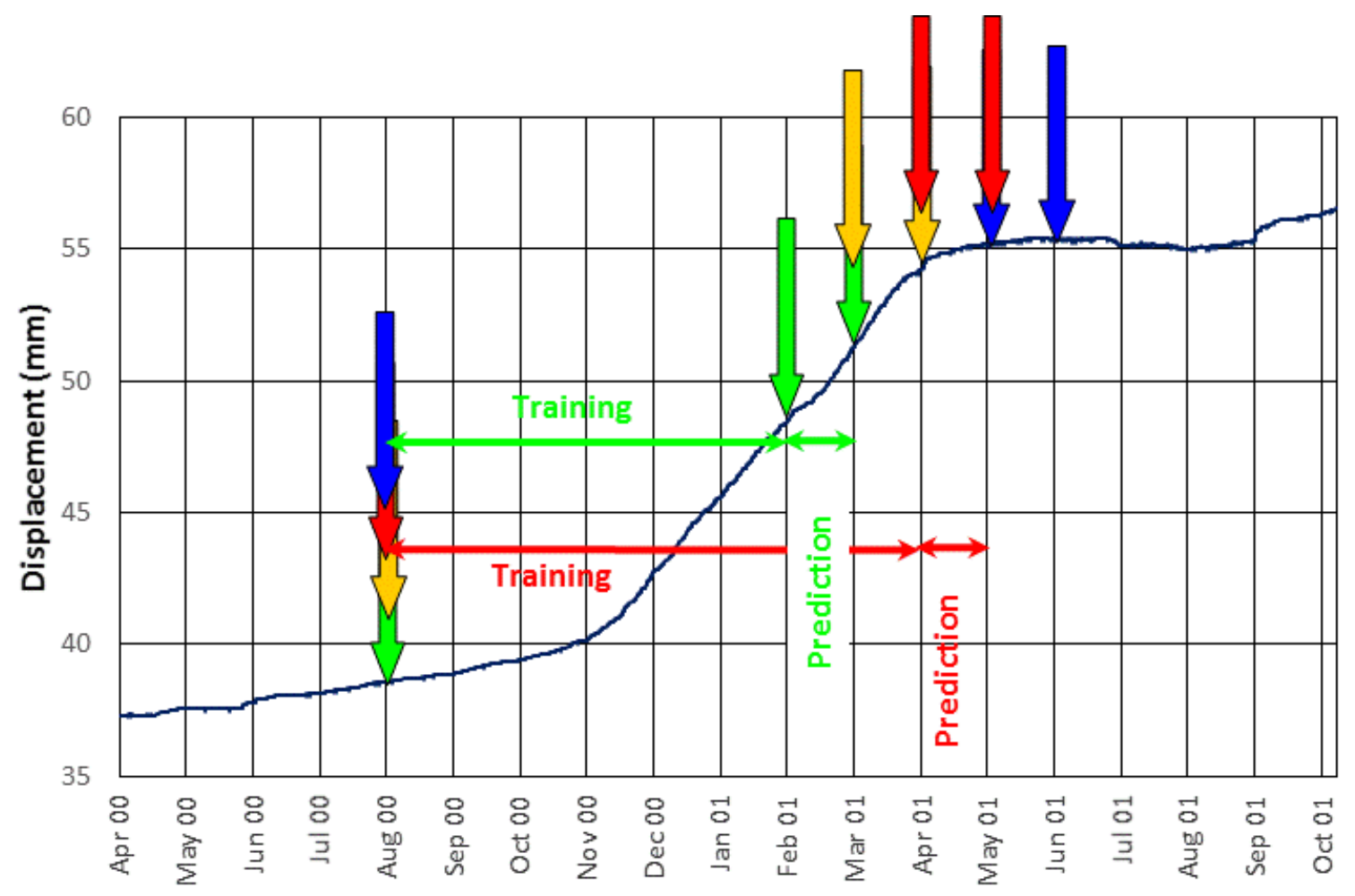

Figure 11: Stepwise training - testing principle (Undercliff landslide). 
Nat. Hazards Earth Syst. Sci. Discuss., https://doi.org/10.5194/nhess-2017-253

Manuscript under review for journal Nat. Hazards Earth Syst. Sci.

Discussion started: 13 July 2017

(c) Author(s) 2017. CC BY 4.0 License.

(c) (i)
Natural Hazards and Earth System

Sciences

Discussions

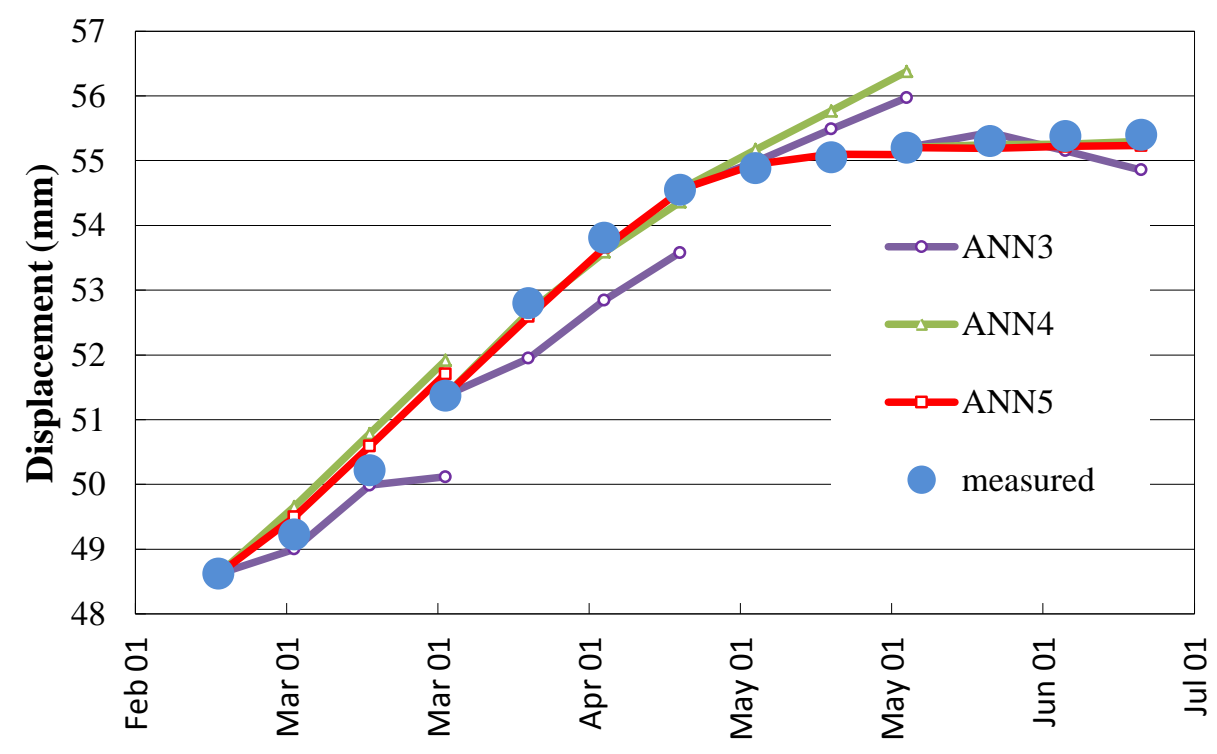

Figure 12: Displacements for a 4 month sequence - Undercliff landslide. ANN prediction in comparison with measured values by crackmeter.

Table 1: Movements and rates of movements of the central part of Macesnik landslide from November 2000 to

December 2003.

\begin{tabular}{lrrrc}
\hline Profile & 5 & 6 & 7 & 8 \\
\hline Total movement (m) & 15.6 & 172.3 & 39.7 & 81.3 \\
Rate of movements (mm/day) & & & \\
Maximum & 50.0 & 600.0 & 160.0 & 310.0 \\
Minimum & 3.0 & 14.2 & 5.2 & 9.0 \\
Average & 14.5 & 164.9 & 60.5 & 85.1 \\
\hline
\end{tabular}

Table 2: Movements and rates of movements observed by crackmeters 1 and 2 on Newport Road, Ventnor Undercliff, Isle of Wight in the period between December 1995 and October 2002.

\begin{tabular}{lrc}
\hline Crackmeter & 1 & 2 \\
\hline Total movement (mm) & 52.9 & 42.6 \\
Rate of movements (mm/day) & \\
Maximum & 0.094 & 0.085 \\
Minimum & 0 & 0 \\
Average & 0.021 & 0.020 \\
\hline
\end{tabular}

